Vlasenko Lev, Ph.D. (Economics), Assistant Professor of International Economic Relations and Marketing Department, Zaporizhzhya Institute of Economics and Information Technologies (ZIEIT), Zaporizhzhya, Ukraine

ORCID: 0000-0002-7723-1734

e-mail: levvlasenko@gmail.com

\title{
History of Ukraine-China Bilateral Trade
}

Annotation. Introduction. During the years of Ukrainian independence, China has risen from a relatively insignificant country in Asia to the biggest trade partner of Ukraine surpassing even Russia and other post-Soviet republics both in amount and the importance of bilateral trade. To fully understand the current dynamics of bilateral trade between Ukraine and China, it is necessary to explore the history of these relations from ancient times to the current stage to improve the strategy for cooperation between Ukraine and China.

Purpose. To study the history of bilateral trade relations of Ukraine and China from first diplomatic contacts to contemporary relations, to identify patterns and trends that affect the dynamics of trade, to outline mistakes and shortcomings of Ukrainian diplomacy, and to provide recommendations for improvement.

Result. The revealed pattern of diplomatic and trade relations between Ukraine and China may be considered as an indicator s that China has been viewing Ukraine as a political entity even before the declaration of independence in 1991. International relations between Ukraine and China have a deep and strong historical tradition with a wide range of forms and methods of cooperation in the fields of politics, economics, and culture.

Conclusions. The revealed dynamics of bilateral trade prove that the negative trends in trade between Ukraine and China are not always related to the competitiveness of the Ukrainian economy or global market conditions and may have resulted from the mistakes and failures of Ukrainian diplomacy. To prevent these mistakes in the future, it is necessary to have qualified specialists trained to work with China and conduct effective negotiations at the highest level and monitor their correct coverage in the official documents and press.

Keywords: international trade; bilateral trade; Ukraine-China trade; Soviet-China trade.

\section{УдК 339.542}

Власенко Л.В., кандидат економічних науку, доцент кафедри міжнародних економічних відносин та маркетингу, Запорізький інститут економіки та інформаційних технологій (ЗIEIT), м. Запоріжжя, Україна

\section{Історія двосторонньої українсько-китайської торгівлі}

Анотація. Протягом останніх тридцяти років Китайська Народна Республіка демонструє безпрецедентні темпи сталого розвитку, який не можуть порушити навіть кризові явища світової економіки. Китай перетворився з регіональної держави на глобального гравця, який займає одну з провідних позицій у глобальній економіці та $\epsilon$ найбільшим виробником та експортером у світі. За роки незалежності України Китай з порівняно незначної за масштабами обсягів співпраці краӥни Азії перетворився на найбільшого та найвпливовішого торговельного партнера України, випередивши Росію та інші країни пострадянського простору. Співпраця між Украӥною та КНР стає дедалі актуальнішою зважаючи на євроінтеграційний курс України та важливість побудови торговельних потоків між Європою та КНР у межах інфраструктурного проєкту «Нового Шовкового Шляху». Для повного розуміння сучасної динаміки торгівлі між Україною та Китаєм необхідно дослідити історію двосторонніх відносин від найдавніших часів до сучасного етапу. Метою цієї статті є вивчення історії двосторонніх торговельних відносин України та Китаю від перших дипломатичних контактів до сучасності, виявлення закономірностей та тенденцій, які впливають на динаміку торгівлі, аналіз помилок та недоліків, що притаманні українській дипломатії та надання рекомендації щодо їі вдосконалення. Наступне дослідження було проведено із застосуванням історико-порівняльного, аналітичного та типологічного методів. Історико-порівняльний метод був використаний для вивчення динаміки двосторонньої торгівлі між Україною та Китаєм, використовуючи статистичні дані за 1913-2018 рр., дослідження включало ретроспективний кількісний аналіз торгівлі (експорт, імпорт, торговий баланс та частка у світовій торгівлі), аналіз структури торгівлі. У результаті дослідження було встановлено, що міжнародні відносини між Україною та Китаєм мають досить глибоку і міцну історичну традицію з широким спектром форм і методів співпраці у сферах політики та економіки. При аналізі динаміки двосторонньої торгівлі та дипломатичних зав'язків було доведено, що негативні тенденції у торгівлі між Україною та КНР не завжди пов'язані з конкурентоспроможністю вітчизняної економіки, а значною мірою, з помилками української дипломатії. Були надані базові рекомендації що до уникнення подібних помилоку майбутньому.

Ключові слова: міжнародна торгівля; двостороння торгівля; українсько-китайська торгівля; радянськокитайська торгівля. 
Problem statement. In the past decade, the People's Republic of China (PRC) demonstrated unprecedented growth and resistance to crises. The Chinese economy manages to expand even during the recession of the global economy and is constantly increasing both in GDP and in the amount of its international trade. During the years of Ukrainian independence, China has risen from a relatively insignificant country in Asia to the biggest trade partner of Ukraine, surpassing even Russia and other post-Soviet republics both in amount and the importance of bilateral trade. To fully understand the current dynamics of bilateral trade between Ukraine and China, it is necessary to explore the history of these relations from ancient times to the current stage to improve the strategy for cooperation between Ukraine and China.

Analysis of the recent research and publications. The historical aspect of relations between Ukraine and China, including the economic aspect, was researched by V. Kikitenko [1], I. Pogoryelova [2], S. Pronj [3], S. Trojan [4]. Soviet-Chinese trade, including the contribution of Soviet Ukraine, was researched by A. Z [5], Mah F [6], and Zhihua Shen [7]. The current stage of trade relations, including their historical aspect, was researched by Ying Wang, Ze Tian, \& Shenyue Xia. [8], H. Zhao, K. Bliumska-Danko, \& X. Lu [9] and in author's previous research [10].

The objectives of the following article is to study the history of bilateral trade relations of Ukraine and China from first diplomatic contacts to contemporary relations, to identify patterns and trends that affect the dynamics of trade, to outline mistakes and shortcomings of the Ukrainian diplomacy, and to provide recommendations for its improvement. The following research was conducted by applying historical-comparative, content analysis, and typology methods. The historical-comparative method was utilized to study the dynamics of Ukraine-China bilateral trade by using the statistical data as early as 1913 and until 2018. The study included the retrospective quantitative analysis of bilateral Ukraine-China trade (export, import, balance of trade, and share in global trade), analysis of trade structure by groups of commodities organized according to the Standard International Trade Classification (SITC). Content analysis and typology methods were used to study the institutional basis of Ukraine-China bilateral trade to determine the place of Ukraine in the hierarchy of China's international relations.

Presentation of the main research material. In historical retrospect, Ukrainian-Chinese international relations have always focused on bilateral trade. The territory of modern Ukraine was an important part of the "northern branch" of the Great Silk Road, which spread from Chang'an city (modern Shaanxi Province) through the Pamir Mountains, Central, and West Asia to the Northern coast of the Azov and Black Seas [3, p.78].

There are no reliable written sources to prove direct diplomatic contacts between the states of Kievan Rus and its successors and China in the XII-XVI centuries. However, since the lands of both modern Ukraine and China were parts of the Great Mongol Empire, we can assume that there were some contacts between the two states [1, p.19].

First documented diplomatic contacts between Ukrainian and Chinese states are attributed to XVII century, when representatives of the Cossack Hetmanate state, including former Hetman Demian Mnohohrishny, participated in the signing of the first official international document concluded between the Russian Empire and Qing China, the Treaty of Nerchinsk (1689). The agreement was translated into Latin by Andriy Bilobotsky, a representative of the Kyiv clergy. In 1700 the Orthodox spiritual mission began to work in China, most of the missioners stationed there received education in the Kyiv-Mohyla Academy [1, p. 27-32; 2].

Official relations between the Ukrainian state and China stopped in the second half of the XVIII century when Cossack Hetmanate lost its independence and ceased to be a subject of international law and economic relations. Despite the cessation of the official diplomatic cooperation, cultural and humanitarian exchange between Ukrainian and Chinese nations intensified due to the existence of large Ukrainian ethnic settlements in the Far East Amur border region (the so-called "Green Ukraine" or "Transcathay") [3, p. 78].

Until the XX century, further contacts with China were carried out as part of Russian-Chinese relations. In 1913 China amounted to $4 \%$ of total Imperial Russia trade $(2.1 \%$ of exports and $6.1 \%$ of imports) with a negative trade balance of $52.6 \mathrm{mln}$ of Imperial rubles (approximately $27.11 \mathrm{mln}$ of US\$) [11].

After the collapse of the Russian Empire, the newly established Ukrainian Soviet Socialist Republic (UkSSR) maintained foreign trade missions and offices in other countries in 1919-1922. However, after the foundation of the Soviet Union (USSR) in 1922, external trade relations of all its constituent Soviet Republics were merged and made subservient to one planning center in Moscow that published only combined statistical indicators. Because of this, it is almost impossible to estimate the exact number of commodities created or imported by the Ukrainian economy in the global Soviet external trade. Given the large number of metallurgical and manufacturing enterprises in UkSSR, we can assume that the Ukrainian contribution to this trade was significant [5-7].

In $1918-1940$ only $0.48 \%$ of the average total trade of the USSR was accounted for China. After the end of the Second World War and the proclamation of the People's Republic of China in 1949, its trade relations and economic cooperation with the USSR increased rapidly, reaching a substantial amount of $21.46 \%$ ( 1849 mln of Soviet Rubles, SUR) in 1955 [12]. The UkSSR took an active role in the development of the Chinese industry. In the 1950-1960s Ukrainian engineers made a particularly significant contribution to the emerging Chinese metallurgy and mechanical engineering. The scientific and technological exchange was not one-sided: the UkSSR received from China technical documentation necessary for the production of high-quality colored varieties of silk [3, p. 79]. 


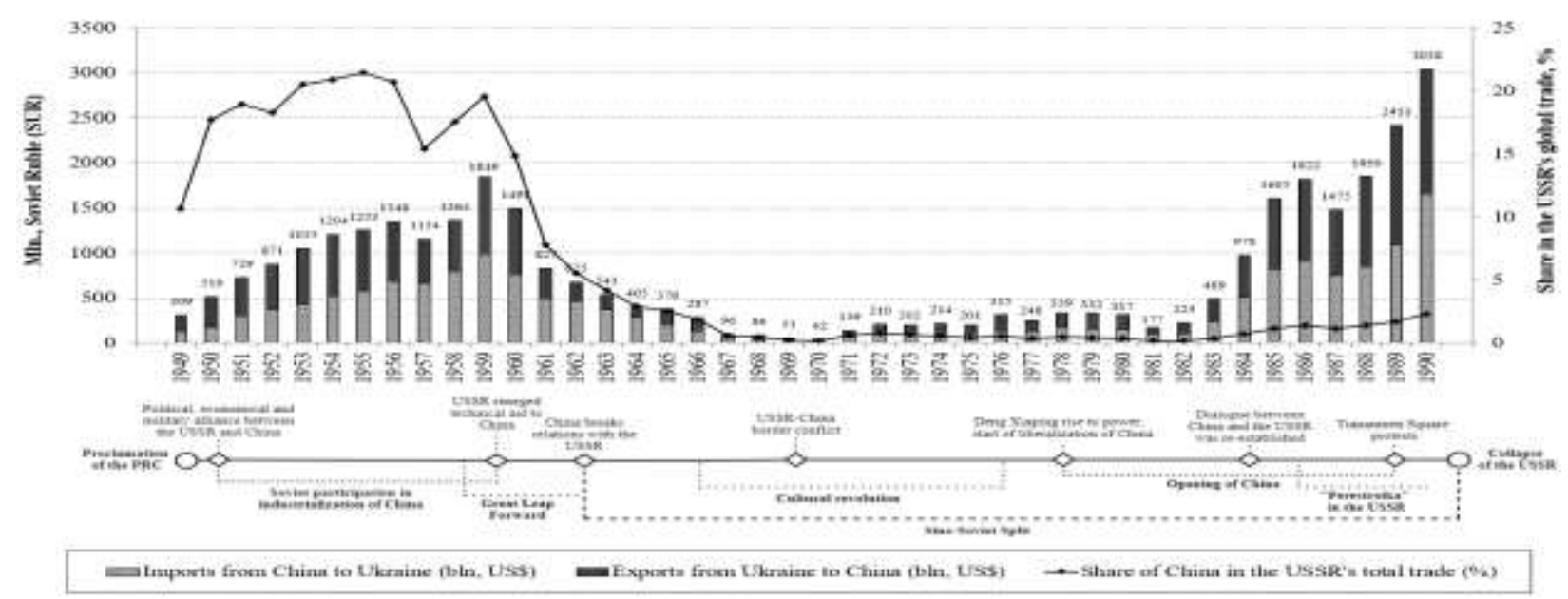

Figure 1 - Timeline of the Soviet-China trade in 1949-1990, $\mathrm{mln}$ of Soviet rubles (SUR)

Source: submitted by the authors basing on sources [12]

As shown in fig 1, trade relations between USSR and China developed on non-market principles and were affected by political disagreements between the two socialist states. In 1960-1989s political and economic relations between PRC and USSR declined because of the doctrinal differences. During the '70s bilateral trade relations suffered a severe drop to almost pre-WW2 level (0.19\%; $42 \mathrm{mln}$ SUR in 1970) and were reconvened only in 1984 , reaching the all-time high amount of $3038 \mathrm{mln}$ SUR (2.31\% of total trade) in 1991 before the collapse of the USSR [12].
While Russia had territorial disputes and border clashes with China, for the UkSSR the conflict was purely ideological and was not attributed to any political, economic, or territorial claims, as evidenced by the rapid resumption of diplomatic relations and bilateral cooperation after the end of the Soviet-era of Ukrainian history.

The contemporary stage of political and economic relations between Ukraine and China began after the collapse of the USSR in 1991. Bilateral trade relations were re-established immediately after the proclamation of Ukrainian independence on August 24, 1991.

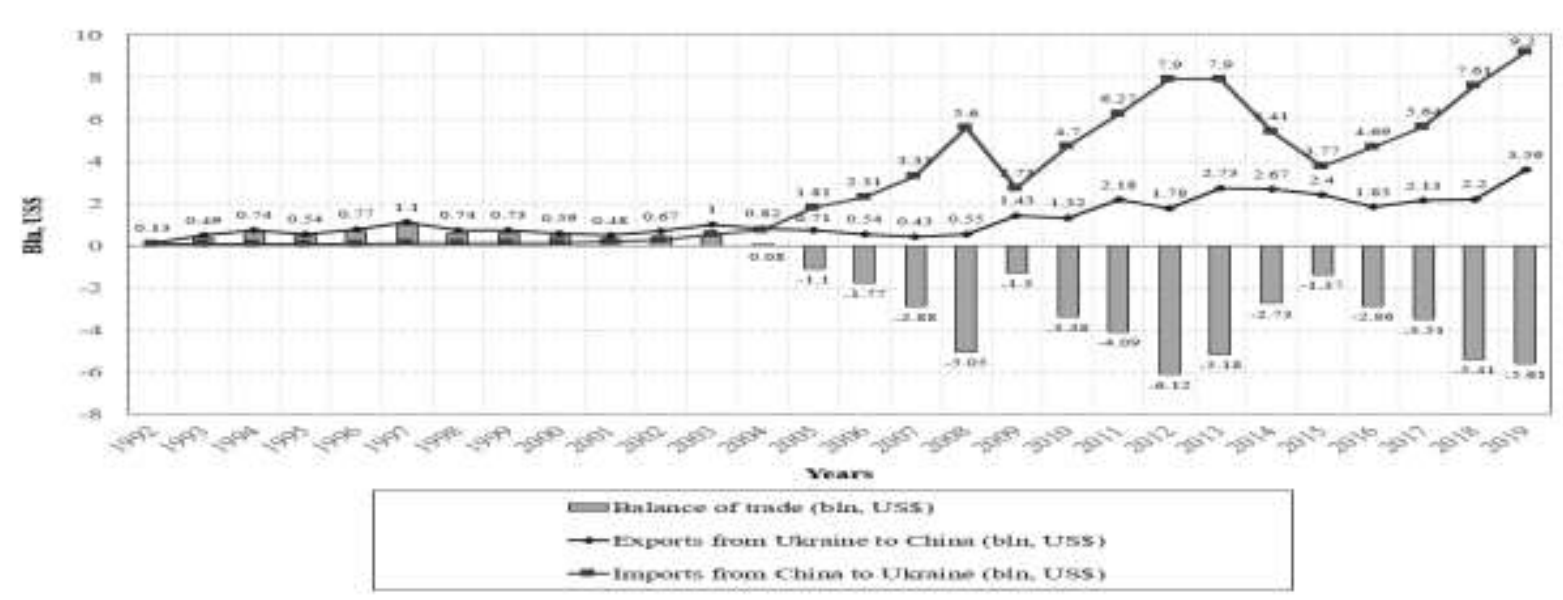

Figure 2 - Dynamics of the basic indicators of bilateral trade in commodities between Ukraine and China in 1992-2019, bln of US\$

Source: submitted by the authors basing on sources [12-13]

In 1992 Ukraine-China total trade amounted to $0.22 \mathrm{bln}$ of US\$ or $0.14 \%$ of total global Chinese trade and $0.66 \%$ of total Ukrainian trade. During the next twenty-seven years, the share of China in Ukrainian global trade steadily increased, reaching $11.57 \%$ (12.79 bln US\$) in 2019 and replacing Russia (10.22\%; 9.25 bln US\$) as the largest Ukrainian trade partner. At the same time, the share of Ukraine in the global Chinese trade remained relatively insignificant (0.26\%; 11.88 bln US\$ in 2019) [12-13]. 
Електронне наукове фахове видання з економічних наук "Modern Economics", №25 (2021), 40-45 https://modecon.mnau.edu.ua | ISSN 2521-6392

Table 1 Share of commodities groups in the structure of bilateral trade between China and Ukraine, \%, 1992, 2008, 2018

\begin{tabular}{|c|l|c|c|c|c|c|c|c|c|}
\hline \multirow{2}{*}{$\begin{array}{c}\text { SITC } \\
\text { Rev. } 4 \\
\text { section } \\
\text { № }\end{array}$} & \multicolumn{1}{|c|}{ Name of categories } & \multicolumn{2}{|c|}{1992} & \multicolumn{2}{|c|}{2008} & \multicolumn{2}{c|}{2018} & \multicolumn{2}{c|}{$\Delta 1992-2018$} \\
\cline { 3 - 10 } & Export & Import & Export & Import & Export & Import & Export & Import \\
\hline $0 ; 1 ; 4$ & $\begin{array}{l}\text { Food and live animals, } \\
\text { beverages, oils, and fats }\end{array}$ & 16.34 & - & 3.01 & 1.4 & 2.53 & 52.12 & -13.81 & +52.12 \\
\hline 2 & $\begin{array}{l}\text { Crude materials, including ores } \\
\text { and slag }\end{array}$ & 31.12 & 1.82 & 5.35 & 69.18 & 5.61 & 38.05 & -25.51 & +36.23 \\
\hline 3 & Mineral fuels & - & - & 0.04 & 7.17 & - & 0.05 & - & +0.05 \\
\hline 5 & Chemicals and related products & 1.91 & 56.22 & 10.5 & 10.25 & 13.88 & 1.41 & 11.97 & -54.81 \\
\hline 6 & $\begin{array}{l}\text { Manufactured goods classified } \\
\text { by material }\end{array}$ & 34.95 & 37.07 & 29.4 & 4.84 & 19.63 & 2.43 & -15.32 & -34.64 \\
\hline 7 & $\begin{array}{l}\text { Machinery and transport } \\
\text { equipment }\end{array}$ & 8.48 & 4.86 & 38.5 & 6.88 & 45.47 & 5.45 & +36.99 & +0.59 \\
\hline $8 ; 9$ & $\begin{array}{l}\text { Miscellaneous manufactured } \\
\text { articles }\end{array}$ & 7.2 & 0.03 & 13.2 & 0.29 & 12.88 & 0.47 & +5.68 & +0.44 \\
\hline
\end{tabular}

Source: submitted by the authors basing on sources [12-13]

The structure of trade changed fundamentally (see table 1). In 1992 China was exporting manufactured goods, mainly textiles and clothing $(29.4 \mathrm{mln}$ of US\$, $32.93 \%$ of total Chinese export to Ukraine) and crude materials, primarily minerals (24.68 $\mathrm{mln}$ US\$; $27.64 \%$ ). In 2018 primary articles of Chinese exports to Ukraine switched to machines and transport equipment, mainly machinery and electrical equipment (2.82 bln US\$; 41.69\%), metals (748 mln US\$; 10.66\%). At the same time, Ukrainian trade with China deteriorated: in 1992, China was mainly importing chemicals (75.4 mln US\$; 56.22\%) and metals (49.2 mln US\$; 36.68\%) from Ukraine, in 2018 import portfolio switched to vegetables (1.21 bln US\$; $46.16 \%)$, minerals (880 mln US\$; 33.4\%) and raw wood (121 mln US\$; 4.62\%) [13].

Analysis of trade patterns demonstrates several ongoing threats to Ukrainian economic security. The balance of trade is negative for Ukraine and the radical changes in the commodity structure of trade with China indicate that Chinese manufacturers currently pose as a direct competitor to Ukrainian industry both in the domestic and foreign markets while China itself consider Ukraine to be a source of cheap raw materials and a transit region to Europe [10]. There is also an assumption that in the future, Ukraine's foreign trade contracts with China may be converted from US dollars to yuan, and arguably this will help to reduce the demand for the US dollar in the Ukrainian foreign exchange market [4].

Despite initially relatively small numbers in bilateral trade, China has been expressing great interest in international cooperation with Ukraine since 1991. China was one of the first countries to recognize the independence of Ukraine on December 27, 1991. In March 1993, the Embassy of Ukraine in China began its activities. After the proclamation of Ukrainian independence, Ukrainian-China diplomatic relations and economic cooperation, including bilateral trade, enjoyed a fresh start with no previous connection to USSR-China political conflicts. There are, however, certain aspects of cooperation that may threaten the stability of political relations between Ukraine and China, one of them is the uncertain status of the province of Taiwan, which is claimed by PRC's but is controlled by the partially recognized Republic of China.

As of the end of 2020, the general legal framework of Ukrainian-Chinese bilateral relations includes more than 300 documents, of which 178 are documents of the main list and 122 - of the additional list (mainly protocols of intergovernmental commissions and sub-commissions, contracts, etc.). The current institutional framework for cooperation is well developed and consists of 220 existing international agreements, 70 of which are directly related to the economy, and 31 contain an economic component related to international trade. On June 20, 2011, both countries signed the Joint Declaration on the establishment and development of strategic partnership between Ukraine and China, this Declaration was further developed by the signing of the Joint Declaration to further deepen the strategic partnership and the Program of the development of strategic partnership between Ukraine and China in 2014-2018 years on December 5, 2013 [14].

The main documents related to Ukraine-China bilateral trade are following: 1) Trade and Economic Cooperation Agreement between Government of Ukraine and Government of the People's Republic of China (1992); 2) Agreement on the establishment of the Joint Business Council between the Ukrainian Chamber of Commerce and Industry and the China Council for the Promotion of International Trade (2010); 3) Ukraine-China Action Plan for the implementation of the initiative to build the economic belt of the Great Silk Road and the Sea Silk Road of the XXI century (2017) [14].

The strong connection between PRC's diplomatic rhetoric and the dynamics of bilateral trade remained intact as evidenced by several occasions when UkrainianChinese trade relations suffered not from economic crises 
or unfavorable market conditions, but because of the failures of Ukrainian diplomacy.

Since 1991 Ukraine and China exchanged 17 reciprocal visits of the high-ranking government officials, including five presidential visits. Every governing leader of the PRC since 1991 (i.e. Jiang Zemin, Hu Jintao, Xi Jinping) visited Ukraine while acting Ukrainian presidents Viktor Yushchenko and Petro Poroshenko never visited China, and both expressed a pro-USA position in international politics. This fact was not overlooked by Chinese partners: presidential terms of both Yushchenko and Poroshenko were distinguished by the lukewarm approach of the Chinese diplomats and considerable setbacks in negotiations, including on the treaties on bilateral trade. This was a stark contrast to previous Ukrainian President Leonid Kuchma who was constantly praised by Chinese media as the "great friend of the Chinese people" [2, p. 83; 14].

During the presidency of Victor Yushchenko, the dialogue between the governments of Ukraine and China has stagnated. The most important setback was the failure to sign the Strategic Partnership Agreement that was prepared during the presidency of Leonid Kuchma. Moreover, during this period, no summit meeting took place, and only 23 intergovernmental documents were concluded, including the trade-related Protocol between Ukraine and China on Access to Markets of Goods and Services in the framework of Ukraine's accession to the WTO, concluded on December 6, 2005 [14].

The reason for the slowdown was a change in the political component of Ukrainian-Chinese relations, namely the nature of the 2004 Ukrainian election campaign, public protests, the proclamation of European integration, and Euro-Atlantic cooperation as a strategic goal of Ukrainian policy. An additional factor in the deterioration of relations was the visits of President of Ukraine Viktor Yushchenko in July 2005 and Prime Minister Yulia Tymoshenko to Japan in March 2009 that was perceived by China's top government as insulting and demonstrative demarche [2, p. 86]. The reaction of China to the visit of the Secretary of the Office of the President of Taiwan Huang Zhifang to Ukraine in 2005 was even more severe. In response to this visit, the representatives of the PRC canceled the scheduled meeting of the commission on trade and economic cooperation [2, p. 83].

A full-fledged dialogue was resumed in 2010-2014, marking the great success of Ukrainian diplomacy with the signing of the Joint Declaration on the Establishment and Development of Strategic Partnership Relations between
Ukraine and China during the state visit of Chinese President Hu Jintao to Ukraine on June 20, 2011 [14].

In 2012-2013, bilateral relations reached the preparation of the Joint Interstate Project "Economic Belt of the New Silk Road", however, the implementation of this large-scale project was disrupted by the political crisis in Ukraine in November 2013. The following events led to a change of government, territorial losses, and the inability to fully implement economic, scientific, technical, and infrastructural agreements with China. This is especially true of projects that were planned to be implemented in the territory of the Autonomous Republic of Crimea, which in 2013 was named a priority region for further Ukrainian-Chinese strategic cooperation [8-9].

The Chinese government repeatedly condemned the anti-government actions during the protests in 2013 but recognized the legitimacy of the new Ukrainian government in 2014. However, the dialogue between Ukraine and PRC decelerated during the presidency of Petro Poroshenko despite the growth in bilateral trade. In 2014-2019 only 36 bilateral treaties and agreements were signed comparing to 60 treaties in 2010-2013, and no significant progress was made on developing the "The New Silk Road" project [8-9].

Conclusion. The pattern of diplomatic and trade relations between Ukraine and China may be considered an indicator that China has been viewing Ukraine as a political entity even before the declaration of independence in 1991. International relations between Ukraine and China have a deep and strong historical tradition with a wide range of forms and methods of cooperation in the fields of culture, politics, and economics. China was one of the first countries that established relations with Ukraine and started to build an institutional framework for cooperation. The revealed dynamics of bilateral trade prove that the negative trends in Ukraine-China trade are not always related to the competitiveness of the domestic economy and may have resulted from the mistakes and failures of Ukrainian diplomacy. It needs to be noted that these failures cannot be attributed to the global confrontation of the USA and China or other external geopolitical factors and can be easily avoided if the diplomacy of bilateral UkrainianChinese relations is studied with proper attention to national specificities and the history of existing relations. To achieve this, it is necessary to have qualified specialists trained to work with China and conduct effective negotiations at the highest level and watch their correct coverage in the official press.

\section{References:}

1. Kikitenko, V (2002). Brief history of Ukrainian sinology. 18 - 1st half of 20 cent. : research, materials, and documents. Kyiv. ISBN $966-$ 02-2570-9 [in Ukrainian].

2. Pogoryelova, I. (2010). Modern Ukrainian-Chinese relations : history of becoming and development. Bulletin of Luhansk Taras Shevchenko National University, 19 (206), 80-89 [in Ukrainian].

3. Pronj, S. (2007). Kytajsjkyj vektor zovnishnjoji polityky Ukrajiny (istorija, vyklyky suchasnosti, perspektyvy) [Chinese vector of Ukraine's foreign policy (history, modern challenges, prospects)]. Naukovi praci Chornomorsjkogho derzhavnogho universytetu imeni Petra Moghyly. Politologhija, 56 (69), 78-81 [in Ukrainian]. 
Електронне наукове фахове видання з економічних наук "Modern Economics», №25 (2021), $40-45$ https://modecon.mnau.edu.ua | ISSN 2521-6392

4. Trojan, S. (2018). Current Ukraine - China relations : problems and perspectives. International Relations : Theory and Practical Aspects, 84-93 [in Ukrainian]. https://doi.org/10.31866/2616-745x.1.2018.133418

5. A. Z. (1955). Trade between China and the Soviet Bloc. The World Today, 11(5), 202-210. Retrieved from : http://www.jstor.org/stable/40392815 [in English].

6. Mah, F. (1964). The Terms of Sino-Soviet Trade. The China Quarterly, 17, 174-191. [in English] https://doi.org/10.1017/S0305741000041734

7. Shen, Zhihua. (2020). A Short History of Sino-Soviet Relations, 1917-1991. [in English]. https://doi.org/10.1007/978-981-13-8641-1

8. Zhao, H., Bliumska-Danko, K., \& Lu, X. (2019). Under the «Belt and Road» initiative, the China and Ukraine governments should assume greater responsibility to promote trade. Bulletin of Sumy National Agrarian University, (3(81), $30-39$ [in Ukrainian]. https://doi.org/10.32845/bsnau.2019.3.6

9. Ying Wang, Ze Tian, \& Shenyue Xia. (2018). Analysis of the Competitiveness and Complementarity of China-Ukraine Trade Cooperation under the Background of «Belt and Road». Proceedings of the 2018 International Conference on Economics, Business, Management and Corporate Social Responsibility (EBMCSR 2018). [in English]. DOI: https://doi.org/10.2991/ebmcsr-18.2018.39.

10. Vlasenko, L., Bublei, H., \& Gheusheva, V. (2019), Ukraine-China Bilateral Trade (2008-2018) : Threats and Opportunities. Vision 2025: Education Excellence and Management of Innovations Through Sustainable Economic Competitive Advantage, 13-14 November 2019, Madrid, Spain. In Press, pp. 5665-5675 [in English].

11. A. P. Korelyn (1995). Rossiia 1913 god : Statistiko-dokumentalny̆ spravochnik [Russia, year 1913: statistical and documental reference book]. Blyc. [in Russian].

12. Vneshnjaja torghovlja SSSR (1949-1990) : statystycheskyj obzor. [USSR's external trade: statistical overview]. Vneshtorghyzdat. [in Russian].

13. International Trade Center. Official web-site. Retrieved from : http://www.trademap.org [ in English].

14. World Bank. World Integrated Trade Solution. Official web-site. Retrieved from : https://wits.worldbank.org [in English].

15. Embassy of Ukraine in the People's Republic of China and Mongolia. Official web-site. Retrieved from : http://china.mfa.gov.ua [in Ukrainian].

Ця робота ліцензована Creative Commons Attribution 4.0 International License 